\title{
Desain Didaktis Materi Kaidah Pencacahan Untuk Siswa SMA Kelas XI
}

\author{
M A Jatmiko, ${ }^{1, a}$ T Herman ${ }^{2}$, J A Dahlan ${ }^{2}$ \\ ${ }^{1}$ Pendidikan Matematika, UIN Syarif Hidayatullah Jakarta \\ Jl. Ir H. Juanda No. 95 Tangerang Selatan, Banten 15412 \\ ${ }^{2}$ Pendidikan Matematika, Universitas Pendidikan Indonesia \\ Jl. Dr.Setiabudhi No. 229, Bandung 40154 \\ e-mail: aanang.jatmiko@uinjkt.ac.id
}

\begin{abstract}
This study aims to develop didactic design on counting rules for senior high school. The didactic design is designed by considering two things the result of the test analysis of learning obstacle instrument and learning trajectory. This didactic design consists of four meetings obtained through the three formal stages performed in the study. The first stage is prospective ie didactic situation analysis before learning in the form of hypothetical didactic design including pedagogical didactic anticipation (ADP), second phase metaped analysis is notthe form of design implementation phase, and last stage is retrospective analysis which is an analysis that relate result of prospective analysis with metaped analysis nottik used to formulate empirik design. The research for preparing the didactic design begins with the provision of difficulties in learning the material of the counting rules and the analysis of the teaching materials. The results of the learning obstacle test show that students experience learning barriers that are categorized into three, namely ontogenic obstacle, didactical obstacle, and epistemological obstacle. The didactic design was implemented to 35 students of class XI in one of the senior high school in South Jakarta. Based on the results of research, didactic design developed this can be used as an alternative teaching materials concept of counting rules to minimize student learning barriers.
\end{abstract}

Keywords: didactical design, counting rules, learning obstacle, and learning trajectory

\begin{abstract}
Abstrak
Penelitian ini bertujuan untuk mengembangkan desain didaktis pada materi kaidah pencacahan untuk siswa SMA kelas XI. Desain didaktis dirancang dengan mempertimbangkan dua hal yaitu hasil analisis uji instrumen learning obstacle dan learning trajectory. Desain didaktis ini terdiri dari empat pertemuan yang diperoleh melalui tiga tahap formal yang dilakukan dalam penelitian berlangsung. Tahap pertama yaitu prospektif yakni analisis situasi didaktis sebelum pembelajaran berupa desain didaktis hipotetik termasuk antisipasi didaktis pedagogis (ADP), tahap kedua analisis metapedadidaktik berupa tahap implementasi desain, dan tahap terakhir adalah analisis retrospektif yang merupakan analisis yang mengaitkan hasil analisis
\end{abstract}


prospektif dengan analisis metapedadidaktik yang digunakan untuk merumuskan desain empirik. Penelitian untuk menyusun desain didaktis diawali dengan pemberian tes kesulitan belajar materi kaidah pencacahan dan analisis terhadap bahan ajar. Hasil tes hambatan belajar menunjukan bahwa siswa mengalami hambatan belajar yang dikatagorikan menjadi tiga, yaitu ontogenic obstacle, dizdactical obstacle, dan epistemological obstacle. Desain didaktis diimplementasikan kepada 35 siswa kelas XI di salah satu Madrasah Aliyah di Jakarta Selatan. Berdasarkan hasil penelitian, desain didaktis yang dikembangkan ini dapat dijadikan salah satu alternatif bahan ajar konsep kaidah pencacahan untuk meminimalkan hambatan belajar siswa.

Kata kunci: desain didaktis, kaidah pencacahan, learning obstacle, dan learning trajectory

\section{PENDAHULUAN}

Pendidikan merupakan aspek yang sangat penting dalam menunjang kemajuan bangsa di masa depan. Melalui pendidikan, manusia sebagai subjek pembangunan dapat dididik, dibina dan dikembangkan potensi-potensinya. Untuk itu dalam menunjang kemajuan pendidikan, pemerintah pun memberikan perhatian besar terhadap pelaksanaan program pendidikan di Indonesia. Hal ini terbukti bahwa pelaksanaan pendidikan di Indonesia telah diatur dalam UndangUndang No. 20 Tahun 2003 Pasal 3, yang merumuskan bahwa pendidikan nasional berfungsi mengembangkan kemampuan dan membentuk watak serta peradaban bangsa yang bermartabat dalam rangka mencerdaskan kehidupan bangsa, bertujuan untuk mengembangkan potensi peserta didik agar menjadi manusia yang beriman, bertakwa kepada Tuhan Yang Maha Esa, berakhlak mulia, sehat, berilmu, cakap, kreatif, mandiri, dan menjadi warga negara yang demokratis serta bertanggung jawab [1].

Pencapaian tujuan pendidikan tersebut menjadi tantangan termasuk peningkatan mutu, relevansi dan efektivitas pendidikan sebagai tuntutan nasional sejalan dengan perkembangan dan kemajuan masyarakat, berimplikasi secara nyata dalam program pendidikan dan kurikulum sekolah. Guru dan murid adalah dua aspek yang penting dalam proses pendidikan di sekolah. Keduanya saling bersinergi satu sama lain, guru tidak dapat mendominasi saat proses pembelajaran 
demikian pula sebaliknya. Hal ini dapat mengakibatkan siswa menjadi kurang kreatif dan inovatif dalam kegiatan pembelajaran matematika.

Kurang kreatif dan inovatif dalam kegiatan pembelajaran matematika dapat mengakibatkan lemahnya kemampuan matematika siswa. Lembaga Trends in International Mathematics and Science Study (TIMSS) pada tahun 2015 melakukan survei terhadap kemampuan matematika siswa Indonesia. Berdasarkan survei tersebut Indonesia memperoleh skor 397, berada pada peringkat ke-45 dari 50 negara [2]. Dilihat dari kompetensi dasar yang dikembangkan berdasarkan standar kompetensi, dapat diperoleh persentase perbandingan antara aspek Bilangan, Aljabar, Geometri dan Pengukuran, Statistika dan Peluang sebesar 15\%, 37\%, 41\%, 7\% [3]. Hal ini mengindikasikan bahwa masih kurangnya kemampuan siswa Indonesia dalam menyelesaikan permasalahan matematika dalam materi peluang yang didalamnya terdapat sub-materi kaidah pencacahan.

Kemampuan berpikir matematik dapat digolongkan pada berpikir tingkat rendah sampai berpikir tingkat tinggi. Mengerjakan perhitungan sederhana dan mengaplikasikan rumus secara langsung digolongkan pada berpikir matematik tingkat rendah. Sedangkan pemahaman yang bermakna, menyusun konjektur, menarik analogi dan generalisasi, penalaran logis, pemecahan masalah, komunikasi dan koneksi matematik digolongkan sebagai berpikir matematik tingkat tinggi. Salah satu kemampuan berpikir tingkat tinggi yang menjadi tujuan mata pelajaran matematika di sekolah adalah pemahaman konsep matematik, hal ini termuat dalam kurikulum matematika sekolah tahun 2013.

Pembelajaran matematika merupakan sebuah proses pengalaman belajar siswa melalui kegiatan yang sudah direncanakan, supaya siswa mencapai kompetensi materi matematika yang dipelajari. Suryadi mengatakan bahwa pada dasarnya pembelajaran matematika berkaitan dengan Guru, Siswa, dan Materi Matematika [4]. Pembelajaran matematika bertujuan untuk mempersiapkan siswa agar dapat mempelajari matematika sebagai pola pikir dalam kehidupan seharihari dan matematika sebagai ilmu. Tugas ini tentu ada pada pundak seorang guru yang menyampaikan materi matematika kepada siswa. 


\section{Hipotenusa}

Pembelajaran matematika secara umum menuntut siswa untuk tidak hanya sekedar mampu memahami suatu konsep matematika, namun juga harus mampu menggunakan matematika tersebut untuk menyelesaikan permasalahan-permasalahan yang lebih rumit dan membutuhkan kemampuan tingkat tinggi seperti pemecahan masalah.

Merujuk pada standar kompetensi yang harus dicapai siswa, maka ruang lingkup materi matematika adalah aljabar, pengukuran dan geomerti, peluang dan statistik, trigonometri, serta kalkulus. Salah satu materi dalam pembelajaran matematika yang dipelajari adalah materi peluang. Peluang dapat diartikan sebagai besar kemungkinan suatu kejadian terjadi dari suatu percobaan. Teori peluang sangat banyak manfaatnya pada kehidupan sehari-hari, contohnya dalam bidang bisnis, meteorologi, sains, dan industri.

Pada bisnis asuransi jiwa, perusahaan asuransi jiwa menggunakan peluang untuk menaksir berapa lama seseorang mungkin hidup; pada bidang kedokteran, dokter menggunakan peluang untuk memprediksi kesuksesan sebuah pengobatan; pada bidang meteorologi, ahli meteorologi menggunakan peluang untuk meramalkan kondisi cuaca; pada bidang sains, peluang digunakan dalam studi kelakuan molekulmolekul dalam suatu gas dan ilmu genetika, peluang juga digunakan untuk memprediksi hasil-hasil sebelum hari pemilihan umum. Selain itu, dalam pembelajaran matematika, materi peluang merupakan ilmu dasar untuk mempelajari konsep matematika lain seperti statistika dan kombinatorik.

Sebelum siswa mempelajari materi peluang, ada materi prasyarat yang harus dikuasai yaitu kaidah pencacahan. Kaidah pencacahan terdiri dari beberapa sub-materi yang dipelajari, seperti aturan perkalian, permutasi, dan kombinasi. Pada materi ini biasanya disajikan permasalahan matematika yang meminta siswa menentukan banyaknya cara dalam menyusun objek. Untuk menyelesaikan masalah tersebut diperlukan pemahaman siswa terkait konsep aturan perkalian, permutasi, dan kombinasi. Biasanya siswa tertukar dalam menggunakan ketiga konsep tersebut. Siswa kesulitan dalam menentukan konsep apa yang digunakan dalam menyelesaikan masalah matematika. Kesulitan 
tersebut ditunjukan oleh hasil penelitian Mawarni pada tes learning obstacle. Kesulitan tersebut diperlihatkan dari salah satu jawaban siswa dalam menyelesaikan masalah kaidah pencacahan. Hal ini terlihat pada salah satu contoh jawaban siswa yang ditunjukan oleh gambar berikut ini [5].

Soal: Suatu pertemuan dihadiri 10 peserta. Berapa banyak jabat tangan yang terjadi jika setiap peserta saling berjabat tangan dengan peserta lainnya?

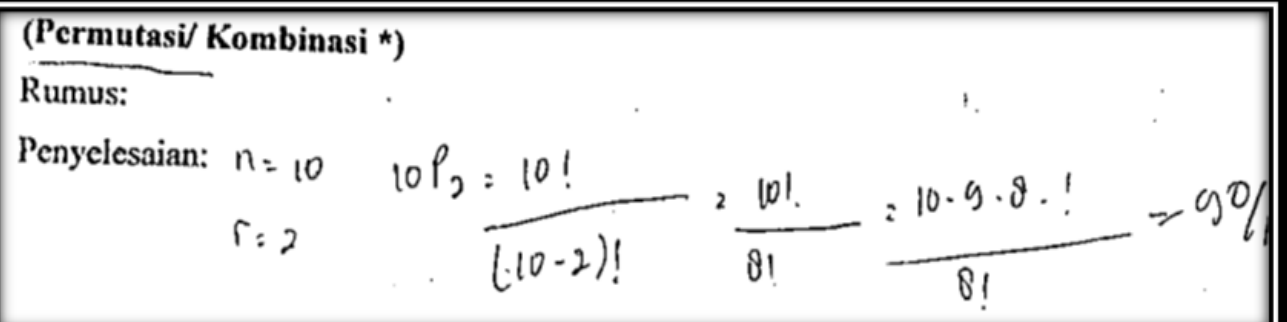

Gambar 1 Contoh jawaban siswa dalam menyelesaikan soal kaidah pencacahan

Jawaban siswa pada Gambar, terlihat bahwa siswa masih belum mampu membedakan soal konsep permutasi atau kombinasi. Seharusnya soal tersebut menggunakan konsep kombinasi karena dalam bersalaman urutan tidak diperhatikan, $(A B=B A)$ artinya kejadian si A bersalaman dengan si B sama dengan kejadian apabila si B bersalaman dengan si A.

Kesalahan siswa dalam menjawab soal tentang kaidah pencacahan juga ditunjukan dalam hasil study pendahuluan yang dilakukan, setelah siswa mendapatkan materi peluang. Siswa belum dapat memanfaatkan pembelajaran materi peluang tersebut terutama pada sub-materi kaidah pencacahan (aturan perkalian, permutasi, dan kombinasi). Siswa hanya sekedar mengetahui dan pernah mempelajari materi kaidah pencacahan, tapi tidak memahami dan mampu menggunakannya dalam pemecahan masalah matematika yang berkaitan dengan materi tersebut. Bahkan materi ini masih dianggap materi yang sulit untuk dipelajari bagi siswa. Kesulitan-kesulitan yang dihadapi siswa tersebut 


\section{Hipotenusa}

Journal of Research Mathematics Education

tentu akan menjadi "batu sandungan" bagi siswa dalam mempelajari materi peluang secara utuh. Hasil analisis study pendahuluan yang dilakukan peneliti dapat ditunjukkan bahwa beberapa siswa mengalami kesulitan dalam memahami materi kaidah pencacahan. Hal ini terlihat pada contoh jawaban siswa seperti yang ditunjukkan oleh gambar berikut ini.

Dalam pelatihan bulutangkis terdapat 10 rang pemain putra dan 8 orang pemain putri. Berapakah pasangan ganda yang dapat diperoleh untuk:

a. Ganda Putra

b. Ganda Putri

c. Ganda Campuran

Jawaban:

$$
\begin{aligned}
& \text { a.) } 10: 2: 5 \Rightarrow \widehat{\otimes \otimes \theta} \otimes \theta \otimes \theta \otimes \theta
\end{aligned}
$$

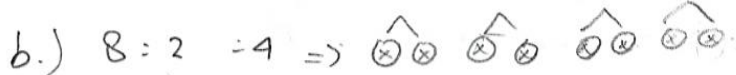

$$
\begin{aligned}
& \text { c. } 18: 2=9
\end{aligned}
$$

Gambar 2 Contoh jawaban siswa dalam menyelesaikan soal kaidah pencacahan

Soal kaidah pencacahan di atas adalah persoalan mencari banyaknya cara yang dapat diperoleh dalam memilih pemain. Untuk dapat menjawabnya, siswa harus bisa mengaitkan konsep kombinasi dengan permasalahan di atas. Penyelesaian soal yang dikerjakan siswa tersebut cenderung menggunakan konsep kombinasi dengan prosedur pembagian sederhana, sehingga menimbulkan kesalahan penafsiran ketika ada 10 orang putra lalu ingin dicari banyaknya pasangan ganda yang diperoleh. Siswa menggunakan konsep pembagian sederhana dengan membagi dua 10 orang putra tersebut dan memperoleh hasil 5 . Sedangkan diketahui bahwa permasalahan tersebut seharusnya diselesaikan dengan prinsip kombinasi, dari n objek dibuat susunan kombinasi $\mathrm{k}$ objek dengan tanpa memperhatikan unsur, sehingga terdapat susunan yang berbeda. Jawaban siswa diatas terlihat bahwa siswa tidak mampu mengaitkan konsep-konsep kaidah pencacahan khususnya pada materi kombinasi sehingga mereka tidak mampu 
memecahkan masalah yang diberikan. Hal ini mengindikasikan bahwa siswa tidak paham materi kombinasi dan mengalami hambatan belajar (learning obstacles).

Munculnya learning obstacles di atas disebabkan oleh siswa yang masih belum paham tentang konsep kombinasi. Hal ini menyebabkan rangkaian situasi didaktis yang dikembangkan berikutnya tidak lagi sesuai dengan lintasan belajar (learning trajectory) yang seharusnya dilalui setiap siswa, yang akhirnya siswa mengalami kesulitan dalam pembelajaran.

Peneliti membuat bahan ajar atau desain didaktis untuk mengatasi learning obstacles yang diperoleh dari hasil tes diagnostik materi kaidah pencacahan yang ditemukan. Selain itu, penelitian ini membahas faktor-faktor yang menyebabkan siswa mengalami kesulitan dalam mempelajari materi kaidah pencacahan. Penulis ingin mengembangkan pembelajaran yang sesuai dengan lintasan belajar siswa, yaitu nantinya penulis ingin melakukan penelitian desain. Dimana didalamnya terdapat: (1) Disain Permulaan, pada fase ini dibuat hypothetical learning trajectory (HLT) atau hipotesis lintasan belajar. Hypothetical Learning Trajectory (HLT) merupakan antisipasi-antisipasi tentang apa yang mungkin akan terjadi, baik proses berpikir siswa yang akan mendapat pembelajaran maupun hal-hal yang akan terjadi dalam proses pembelajaran. (2) Eksperimen, pada fase ini desain yang sudah dirancang diujicobakan. (3) Analisis Tinjauan, pada fase ini menganalisis data yang sudah dieksperimenkan [6].

\section{METODE PENELITIAN}

Tujuan dari penelitian ini adalah untuk: (1) Mengetahui karakteristik learning obstacle yang dialami siswa terkait materi kaidah pencacahan di SMA; (2) Menyusun desain didaktis awal yang dapat meminimalisir learning obstacle yang telah diidentifikasi dalam mempelajari materi kaidah pencacahan di SMA; (3) Mengetahui hasil implementasi desain didaktis awal yang telah disusun berdasarkan 


\section{Hipotenusa}

learning obstacle; (4) Menyusun desain didaktis revisi materi kaidah pencacahan di SMA.

Subjek dalam penelitian ini adalah siswa di salah satu Madrasah Aliyah di Jakarta Selatan. Subjek penelitian pada kelompok pertama adalah siswa yang akan mengikuti Tes Kemampuan Responden (TKR) Awal untuk mendapatkan learning obstacles pada siswa, yaitu mereka yang sudah mendapatkan pelajaran materi kaidah pencacahan. Jadi pada kelompok pertama ini, respondennya adalah siswa SMA Kelas XII. Subjek penelitian pada kelompok kedua yaitu siswa SMA Kelas XI. Kelompok kedua ini yang akan mendapatkan pembelajaran menggunakan desain didaktis, hal ini disesuaikan dengan kompetensi inti dan kompetensi dasar pelajaran matematika SMA Kelas XI.

Desain dalam penelitian ini menggunakan penelitian kualitatif yang dilakukan dalam dua tahap dan menekankan pada karakter penelitian deskriptif dengan data yang dikumpulkan berupa kata-kata, gambar, dan bukan angka-angka. Penelitian ini bermaksud untuk memahami fenomena tentang apa yang dialami oleh subjek penelitian, misalnya perilaku, persepsi, motivasi, tindakan, dan lain-lain secara holistik [7]. Langkah-langkah formal dalam penelitian desain didaktis ini adalah sebagai berikut; (1) Analisis situasi didaktis sebelum pembelajaran berupa desain didaktis hipotetik termasuk ADP; (2) Analisis metapedadidaktik; (3) Analisis retrospektif berupa analisis yang mengaitkan hasil analisis situasi didaktis hipotetik dengan hasil analisi metapedadidaktik [8].

Pemilihan disain penelitian ini didasarkan pendapat Drew C. J. et al yang dikenal dengan natural state argument: one ethical persepective is that the researcher has the responbility to provide the new treatment to all participant [9]. Hasil akhir yang diharapkan adalah suatu rumusan bagi desain didaktis baru yang dapat diimplementasikan sebagai upaya perbaikan dalam proses bembelajaran dikelas, sehingga kemampuan siswa dapat dikembangkan dengan optimal.

Analisis data dalam penelitian ini berlangsung pada sejak sebelum penulis memasuki lapangan hingga implementasi berlangsung. Sebelum memasuki lapangan, analisis dilakukan dari hasil data studi 


\section{Hipotenusa}

Journal of Research Mathematics Education

VOL.4 NO.12021

pendahuluan yang akan digunakan untuk menentukan focus penelitian. Analisis data kualitatif menurut Bogdan \& Biklen adalah upaya yang dilakukan dengan jalan bekerja dengan data, mengorganisasikan data, memilah-milahnya menjadi satuan yang dapat dikelola, mensintesiskannya, mencari dan menemukan pola, menemukan apa yang penting dan apa yang dipelajari, dan memutuskan apa yang dapat diceritakan kepada orang lain [7]. Sementara itu Creswell menjelaskan bahwa analisis data merupakan proses berkelanjutan yang membutuhkan refleksi terus-menerus terhadap data dan menulis catatan singkat sepanjang penelitian [10].

Penulis ingin merumuskan suatu langkah-langkah yang akan digunakan sebagai acuan dalam melakukan penelitian. Langkah-langkah tersebut akan dipresentasikan dalam bentuk diagram. Berikut merupakan diagram alur penelitian yang dirancang oleh penulis: 


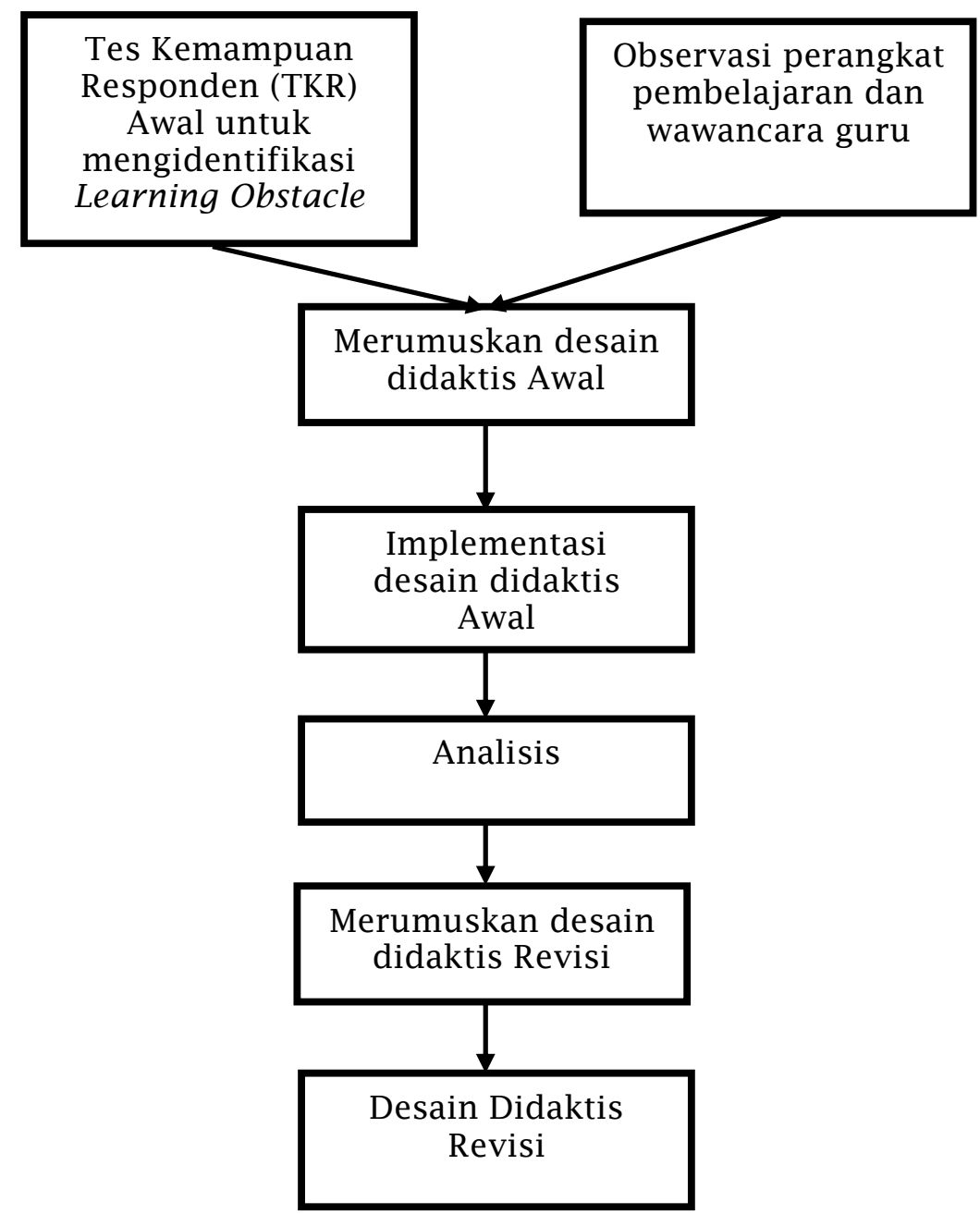

Gambar 3 Diagram Alur Penelitian

\section{HASIL DAN PEMBAHASAN}

Berdasarkan hasil analisis instrument tes diagnostik untuk menguji learning obstacle, maka disusunlah leaning trajectory hipotetik untuk 4 kali pertemuan. Leaning trajectory yang disusun terdiri dari hipotesis alur materi pembelajaran yang memuat konsep, fakta, prinsip, dan prosedur kaidah pencacahan serta hipotesis kesalahan siswa yang mungkin terjadi sehingga dapat dibuat antisipasi-antisipasi sebagai solusi untuk meminimalisir learning obstacle yang siswa lakukan. Alur pembelajaran ini dibuat untuk membantu dalam menyusun desain didaktis hipotetik materi kaidah pencacahan, sehingga dalam 
penyusunannya dapat merangkum beberapa materi yang seharusnya diajarkan kepada siswa.

Pengembangan desain didaktis hipotetik merupakan hasil dari berbagai pertimbangan yang peneliti lakukan. Pertimbangan tersebut berdasarkan beberapa hal, yaitu: 1) Mempertimbangkan hasil analisis tes diagnostik berupa analisis learning obstacle, analisis buku paket matematika SMA kelas XI, dan analisis penelitian yang relevan; 2) Menyesuaikan hypotetical learning trajectory yang telah disusun; 3) Berdasarkan teori situasi didaktis. Desain didaktis hipotetik materi kaidah pencacahan yang dirancang terbagi menjadi 4 lesson design. Disetiap lesson design yang dirancang terbagi menjadi beberapa situasi pembelajaran yang dibuat untuk mengatasi learning obstacle yang terjadi pada siswa.

Berikut merupakan implementasi desain yang dilakukan di salah satu Madrasah Aliyah di Jakarta Selatan. Desain didaktis hipotetik di implementasikan pada kelas XI A dengan siswa sebanyak 35 orang.

Tabel 1. Persentase Jawaban Siswa pada Implementasi Lesson Design

\begin{tabular}{|c|c|c|c|c|}
\hline Lesson Design & Situasi & Benar(\%) & $\operatorname{Salah}(\%)$ & Tidak Jawab(\%) \\
\hline \multirow{4}{*}{1} & 1 & 88,57 & 11,43 & - \\
\hline & 2 & 20,00 & 80,00 & - \\
\hline & 3 & 82,86 & 17,14 & - \\
\hline & 4 & 60,00 & 40,00 & - \\
\hline \multirow{5}{*}{2} & 1 & 51,43 & 48,57 & - \\
\hline & 2 & 80,00 & 20,00 & - \\
\hline & 3 & 94,29 & 5,71 & - \\
\hline & 4 & 74,29 & 25,71 & - \\
\hline & 5 & 65,71 & 28,57 & 5,71 \\
\hline \multirow{3}{*}{3} & 1 & 82,86 & 17,14 & - \\
\hline & 2 & 8,57 & 77,14 & 14,29 \\
\hline & 3 & 14,29 & 74,29 & 11,43 \\
\hline
\end{tabular}




\begin{tabular}{lllll} 
& 4 & 71,43 & 28,57 & - \\
4 & 1 & 85,71 & 14,29 & - \\
& 2 & 60,00 & 40,00 & - \\
\hline
\end{tabular}

Berdasarkan analisis yang dilakukan terhadap setiap situasi padan rancangan lesson design 1 sampai dengan 4, dan melihat keterkaitannya pada respon siswa saat implementasi atau dalam teori DDR (Design Didactical Research) dikenal dengan istilah analisis retrospektif, terdapat beberapa rekomendasi untuk merevisi desain didaktis hipotetik. Berikut merupakan desain didaktis revisi materi kaidah pencacahan.

\section{Revisi Situasi 2 Lesson Design 1}

Situasi 2 pada lesson design 1 tetap dipertahankan redaksi kalimat serta prediksi dan antisipasinya seperti pada desain hipotetik, tetapi dilakukan revisi terkait gambar pohon. Gambar yang dimaksud dapat mempengaruhi cara pemahaman siswa, sehingga siswa salah persepsi dalam memahami perintah soal. Berikut merupakan perbaikan yang dilakukan pada situasi 2 lesson design 1.

\section{Masalah 2}

B. Membuat Diagram Pohon Dalam Menentukan Banyaknya Cara Pengaturan Objek

1. Perhatikan soal berikut ini:

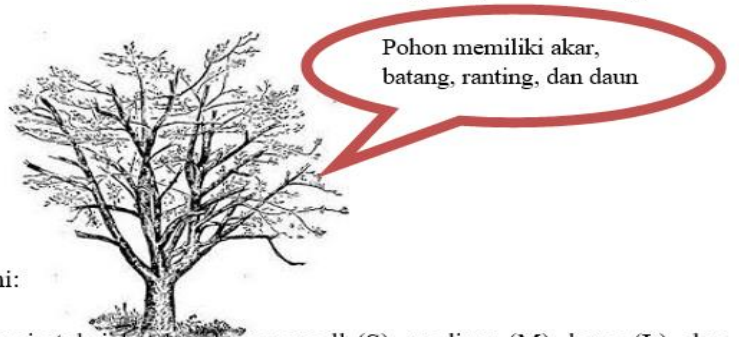

Sebuah toko jaket mempunyai stok jaket beruktiran small (S), medium (M), large (L), dan extra large (XL), serta semua ukuran tersedia dalam warna biru (B) dan hijau (H). Bantulah pekerja toko tersebut untuk mendaftar susunan antara ukuran jaket dan warna jaket dengan menggunakan diagram pohon! Kemudian tentukan jumlah pasangan yang mungkin terjadi! 


\begin{abstract}
Masalah 2
B. Membuat Diagram Pohon Dalam Menentukan Banyaknya Cara Pengaturan Objek

1. Perhatikan soal berikut ini:

Sebuah toko jaket mempunyai stok jaket berukuran small (S), medium (M), large (L), dan extra large (XL), serta semua ukuran tersedia dalam warna biru (B) dan hijau (H). Bantulah pekerja toko tersebut untuk mendaftar susunan antara ukuran jaket dan warna jaket dengan menggunakan diagram pohon! Kemudian tentukan jumlah pasangan yang mungkin terjadi!
\end{abstract}

Gambar 4 Revisi Desain Didaktis Situasi 2 Lesson Design 1

Gambar pohon yang terdapat pada lesson design hipotetik dieliminasi bertujuan agar siswa tidak salah dalam memahami diagram pohon. Diagram pohon yang dimaksud merupakan garis-garis yang mewakili akar, batang, dan ranting yang saling terhubung untuk memasangkan banyaknya objek.

\title{
Revisi Situasi 2 Lesson Design 2
}

Lesson design 2 membahas mengenai konsep, prinsip, dan prosedur pada faktorial. Untuk memahami mengenai prosedur faktorial, salah satunya dilakukan dengan cara melatih siswa dalam operasi hitung penjumlahan dan pengurangan pada faktorial. Peneliti membuat situasi yang terdiri dari soal yang menerapkan penjumlahan dan pengurangan faktorial. Pada saat penerapan situasi terdapat jawaban siswa yang diluar prediksi dikarenakan pada situasi sebelumnya siswa hanya diminta untuk menguraikan bilangan faktorial. Jawaban siswa yang diluar prediksi yaitu, siswa hanya menguraikan bilangan faktorialnya saja, tetapi tidak menghitungnya, ataupun tidak melakukan operasi hitung penjumlahan maupun pengurangan. Berdasarkan analisis retrospektif peneliti merevisi situasi 2 dengan memberikan antisipasi yang ditambahkan pada kolom dukungan guru. Antisipasi yang diberikan diharapkan dapat mencegah respon siswa yang diluar prediksi. Berikut redaksi antisipasi yang ditambahkan "Guru bertanya kepada siswa, apa yang diinstruksikan oleh soal? Hanya 


\section{Hipotenusa}

Journal of Research Mathematics Education

menguraikan faktorialnya saja atau sampai pada hasil perhitungannya?". Pernyataan berikut diharapkan dapat mengarahkan siswa dalam menyelesaikan jawaban sampai pada hasil perhitungan.

\section{Revisi Situasi 2 Lesson Design 3}

Pada situasi kedua yang terdapat pada lesson design 3 siswa diminta untuk menurunkan rumus permutasi dari unsur-unsur yang berbeda. Pada implementasi lesson design 3, tidak ada siswa yang berhasil menjawab dengan benar dalam menurunkan rumus permutasi. Berdasarkan analisis retrospektif terkait situasi 2 pada soal nomor dua, dilakukan revisi pada redaksi soal. Revisi yang dilakukan disajikan pada gambar berikut ini.

\footnotetext{
2. Jika pada soal nomor 1 tadi kita buat sedemikian hingga ada $\mathrm{n}$ buah bola yang berbeda warnanya dan $r$ buah kotak dengan syarat $(r \leq n)$, buatlah ilustrasi dari soal berikut dari kotak ke-1, kotak ke-2, kotak ke-3, kotak ke-4, sampai kotak ke-r. Kemudian simpulkan jawaban kalian.
}

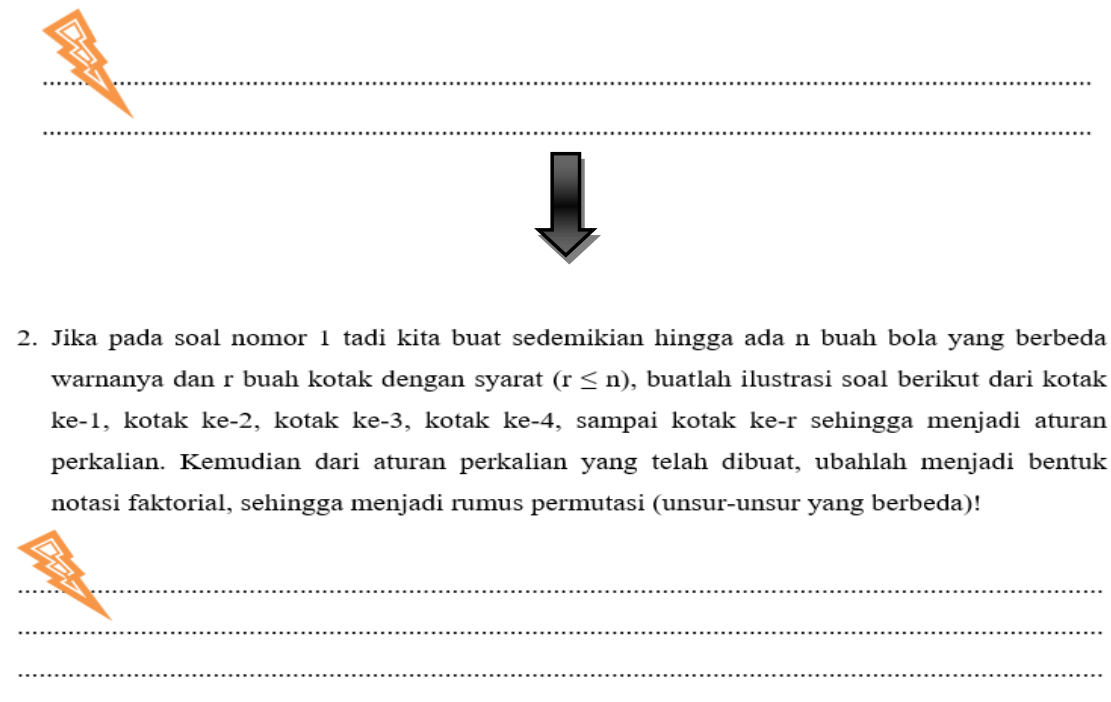

Gambar 5 Revisi Desain Didaktis Situasi 2 Lesson Design 3

Revisi yang diberikan diharapkan dapat membantu siswa dalam langkah-langkah menemukan rumus permutasi dari unsur-unsur yang berbeda. Redaksi kaimat yang terdapat pada revisi soal dapat menuntun siswa sampai pada hasil akhir yang diinginkan. Karena revisi yang 


\section{Hipotenusa}

Journal of Research Mathematics Education

VOL.4 NO.12021

diberikan sudah disesuaikan dengan alur jawaban siswa pada soal nomor 1 dengan situasi yang sama.

\section{Revisi Situasi 3 Lesson Design 3}

Masih dalam materi yang sama pada revisi sebelumnya, siswa sulit dalam menurunkan rumus permutasi dari unsur-unsur yang sama. Kendala yang dialami sama dengan pada saat implementasi situasi 2 pada lesson design yang sama. Berdasarkan analisis retrospektif, dilakukan revisi dari situasi yang ada pada lesson design hipotetik. Revisi tersebut dilakukan dalam redaksi kalimat soal. Berikut merupakan revisi yang dilakukan pada situasi 3 pada soal nomor 3 .

3. Simpulkanlah rumus yang tepat untuk menentukan permutasi dari unsur-unsur yang sama berdasarkan soal nomor 1 dan 2

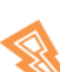

1.

......................

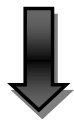

3. Jika pada soal nomor 2 tadi kita buat sedemikian hingga ada $\mathrm{n}$ buah bendera dan terdapat $\mathrm{k}_{1}$ bendera berwarna sama, $\mathrm{k} 2$ bendera berwarna sama, $\mathrm{k}_{3}$ bendera berwarna sama, sampai dengan $\mathrm{k}_{\mathrm{n}}$ bendera berwarna sama dengan syarat $\left(\mathrm{k}_{1}+\mathrm{k}_{2}+\mathrm{k}_{3}+\ldots+\mathrm{k}_{\mathrm{n}} \leq \mathrm{n}\right)$. Kemudian simpulkanlah sehingga menjadi rumus permutasi (unsur-unsur yang sama)!

Gambar 6 Revisi Desain Didaktis Situasi 3 Lesson Design 3

Revisi yang diberikan yaitu menambah redaksi pada soal yang menuntun siswa untuk dapat menyelesaikan masalah yang diberikan yaitu, menurunkan rumus permutasi dari unsur-unsur yang sama. Redaksi yang dibuat sudah disesuaikan dengan alur jawaban siswa pada soal nomor 2 situasi 3. Hal tersebut dapat memudahkan siswa dalam menentukan prosedur yang dilakuakan, sehingga tidak ada lagi siswa yang berhenti ditengah jalan dalam menyelesaikan masalah. 


\section{Revisi Kesimpulan Pembelajaran}

Pada setiap akhir lesson design yang dirancang, siswa diminta untuk menyimpulkan materi yang telah dipelajari. Kesimpulan yang dimaksud peneliti adalah menjelaskan tentang definisi konsep dan uraian prinsip. Pada saat implementasi lesson design 1, beberapa siswa menyimpulkan pembelajaran dengan menceritakan apa yang dia lakukan selama pembelajaran berlangsung. Jawaban tersebut sama sekali tidak terkait dengan konten isi pembelajaran yang diberikan. Berdasarkan analisis retrospektif, dilakukan revisi terkait redaksi kalimat perintah dalam menyimpulkan pembelajaran. Berikut disajikan revisi yang dilakukan pada kesimpulan pembelajaran.

E. Kesimpulan Pembelajaran

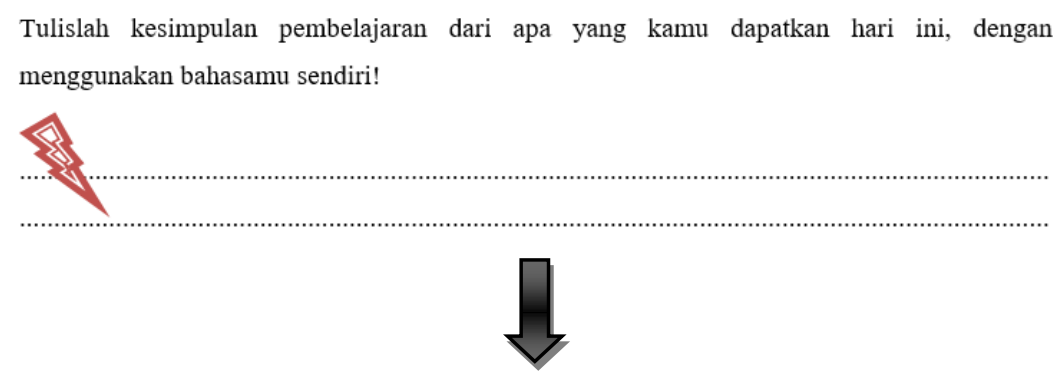

E. Kesimpulan Pembelajaran

Tulislah kesimpulan pembelajaran mengenai konsep dan prinsip aturan perkalian dalam bentuk definisi dan rumus, dengan menggunakan bahasamu sendiri!

Gambar 7 Revisi Desain Didaktis Kesimpulan Pembelajaran pada Lesson Design

Revisi yang dilakukan dengan menambahkan redaksi kalimat yang langsung meminta siswa untuk mendefinisikan konsep maupun uraian materi. Redaksi tersebut dikaitkan dengan materi pada masingmasing lesson design. 
Alur belajar hipotetik yang disusun bertujuan supaya siswa dapat lebih memahami dan mengkonstruk konsep, fakta, prinsip, dan prosedur dalam kaidah pencacahan. Hypotetical learning trajectory yang telah dibuat tidak berhenti sampai disini, jika dalam implementasi desain didaktis materi kaidah pencacahan ditemukan adanya permasalahan-permasalahan baru dan dalam analisis retrospektif diperlukan adanya perubahan alur belajar berdasarkan permasalahan baru yang ditemukan, maka peneliti akan menyusun learning trajectory revisi.

Pengembangan desain didaktis hipotetik merupakan hasil dari berbagai pertimbangan yang peneliti lakukan. Pertimbangan tersebut berdasarkan beberapa hal, yaitu: 1) Mempertimbangkan hasil analisis tes diagnostik berupa analisis learning obstacle, analisis buku paket matematika SMA kelas XI, dan analisis penelitian yang relevan; 2) Menyesuaikan hypotetical learning trajectory yang telah disusun; 3) Berdasarkan teori situasi didaktis. Desain didaktis hipotetik materi kaidah pencacahan yang dirancang terbagi menjadi 4 lesson design. Disetiap lesson design yang dirancang terbagi menjadi beberapa situasi pembelajaran yang dibuat untuk mengatasi learning obstacle yang terjadi pada siswa.

\section{KESIMPULAN DAN SARAN}

Berdasarkan hasil penelitian diperoleh beberapa kesimpulan sebagai berikut: (1) Learning obstacle yang teridentifikasi pada penelitian desain didaktis materi kaidah pencacahan meliputi ontogenic obstacle, didactical obstacle, dan epistemological obstacle. Ketiga jenis learning obstacle tersebut teridentifikasi dari hasil jawaban siswa kelas XII SMA pada tes diagnostik kesulitan belajar materi kaidah pencacahan, hasil analisis wawancara, dan analisis buku paket matematika. Hambatan-hambatan tersebut dibuktikan dengan munculnya kesulitan siswa terkait dengan pengetahuan konsep kaidah pencacahan, pemahaman prinsip kaidah pencacahan, dan prosedur menyelesaikan 


\section{Hipotenusa}

Journal of Research Mathematics Education VOL. 4 NO.1 2021

masalah kaidah pencacahan; (2) Desain hipotetik disusun berdasarkan hasil analisis learning obstacle, hypothetical learning trajectory, dan memperhatikan theory of didactical situation untuk mengatasi atau meminimalkan hambatan yang dialami oleh siswa dalam memahami materi kaidah pencacahan. Desain didaktis tersebut dipartisi menjadi empat buah lesson design yang terdiri dari: (a) Desain didaktis untuk memahami konsep, prinsip, prosedur aturan perkalian; (b) Desain didaktis untuk memahami konsep dan prinsip factorial; (c) Desain didaktis untuk memahami konsep, prinsip, dan prosedur permutasi; (d) Desain didaktis untuk memahami konsep, prinsip, dan prosedur kombinasi serta membedakan penerapan antara permutasi dengan kombinasi; (3) Implementasi pada setiap lesson design dilakukan pada satu kelas dengan peneliti sebagai guru yang melaksanakan pembelajaran. Siswa menyelesaikan setiap situasi yang telah disusun dalam bentuk Worksheet yang dilakukan secara individu dan dilanjutkan dengan diskusi kelompok. Implementasi dari setiap lesson design memunculkan respon (jawaban) yang sesuai dengan prediksi dan yang tidak sesuai dengan prediksi. Proses bimbingan sangat diperlukan terutama dalam proses abstraksi situasi nyata ke dalam konsep mencacah termasuk dalam tahapan penarikan kesimpulan; (4) Analisis retrospektif terhadap hasil implementasi memunculkan beberapa perubahan terkait situasi-situasi yang terdapat pada setiap lesson design, sehingga dihasilkan suatu desain didaktis empirik. Struktur kalimat perintah dan pertanyaan, eliminasi gambar serta penambahan aktivitas tertentu didalam beberapa situasi yang ditambahkan pada desain empirik dengan tujuan dapat lebih mempermudah dan mengkonstruksi pemahaman siswa.

Berdasarkan hasil simpulan pada penelitian, diperoleh rekomendasi sebagai berikut: (1) Desain didaktis pada materi kaidah pencacahan ini dapat menjadi solusi dalam pembelajaran dengan karakteristik siswa yang sama, guru dapat mengantisipasi respon siswa yang kesulitan dalam memahami materi kaidah pencacahan; (2) Desain didaktis empirik materi kaidah pencacahan hasil dari analisis retrosfektif direkomendasikan untuk di implementasikan kembali 
melalui ketiga tahapan DDR, sehingga diperoleh suatu desain didaktis yang dapat lebih meminimalisir kembali kekurangan pada desain yang diperoleh termasuk learning obstacle. Proses implementasi dilakukan pada sekolah yang memiliki karakteristik siswa yang serupa dengan dengan sekolah tempat implementasi; (3) Desain didaktis yang telah dikembangkan pada penelitian ini dapat di implementasikan untuk mengetahui peningkatan hasil belajar siswa atau kemampuan matematika yang lainnya pada penelitian kuantitatif.

\section{DAFTAR PUSTAKA}

[1] Sanjaya, W. (2010). Strategi pembelajaran berorientasi standar proses pendidikan. Jakarta: Kencana Prenada Grup.

[2] Rahmawati. (2016). Hasil TIMSS 2015: Diagnosa hasil untuk perbaikan mutu dan peningkatan capaian. Jakarta: Kemendikbud

[3] Setiadi. (2012). Kemampuan matematika siswa SMP Indonesia: Menurut benchmark internasional TIMSS 2011. Jakarta: Kemendikbud

[4] Suryadi, D. (2010). Metapedadidaktik dan didactical design research (DDR): Sintesis hasil pemikiran berdasarkan lesson study. Bandung: FPMIPA UPI.

[5] Mawarni. (2015). Desain didaktis materi permutasi dan kombinasi pada pembelajaran matematika kelas XI program IPA MAN 1 Banjarmasin. Skripsi pada Pendidikan Matematika FTK IAIN Antasari: tidak diterbitkan

[6] Mulyana, T. (2012). Pengembangan bahan ajar melalui desain penelitian. Bandung: Jurnal Ilmiah Program Studi Matematika STKIP Siliwangi

[7] Moleong, J., L., Prof., Dr. (2009), Metode penelitian kualitatif. Bandung: PT. Remaja Rosdakarya.

[8] Suryadi, D. (2010). Menciptakan proses belajar aktif: kajian dari sudut pandang teori belajar dan teori didaktik. Makalah pada Seminar Nasional Pendidikan Matematika di UNP. Tidak diterbitkan

[9] Drew, C. J., Hardman, M. L., dan Hosp, J. L. (2008). Designing and conducting research in education. California: Sage Publication, Inc. 


\section{Hipotenusa}

Journal of Research Mathematics Education

VOL. 4 NO.1 2021

e-ISSN: $2723-486 X$

p-ISSN: 2621-0630

[10] Creswell, J. (2013). Research design pendekatan kualitatif, kuantitatif, dan mixed. Yogyakarta: Pustaka Pelajar. 